\title{
Electricity generation and color removal at sulfate-reducing conditions in microbial fuel cell
}

\author{
Akgul V. ${ }^{1}$, Cirik K..$^{*}$, Duyar A. ${ }^{3}$, Basak S. ${ }^{4}$, Akman D. ${ }^{1}$ \\ ${ }^{1}$ Department of Bioengineering and Sciences, Kahramanmaras Sutcu Imam University, Kahramanmaras 46100, Turkey \\ 2Department of Environmental Engineering, Kahramanmaras Sutcu Imam University, Kahramanmaras 46100, Turkey \\ ${ }^{3}$ Department of Environmental Engineering, Suleyman Demirel University, Isparta 32260, Turkey \\ ${ }^{4}$ Department of Occupational Health and Safety, Artvin Coruh University, Artvin 08000, Turkey \\ Received: 23/10/2018, Accepted: 10/06/2019, Available online: 13/06/2019 \\ *to whom all correspondence should be addressed: e-mail: kcirik@ksu.edu.tr \\ https://doi.org/10.30955/gnj.002926
}

\section{Abstract}

The main aim of this study is to investigate the simultaneous azo dye removal and bioelectricity production at sulfate-reducing conditions in a continuously fed dual-chamber microbial fuel cell (MFC). Initially, optimization of sulfate reduction was performed at different sulfate concentrations $(100-900 \mathrm{mg} / \mathrm{L})$ and the constant COD of $1000 \mathrm{mg} / \mathrm{L}$, corresponding to COD/sulfate ratio of 1.11-10, and varying HRT of 12-48 h. Optimum COD/sulfate ratio and HRT was found 1.66 and $36 \mathrm{~h}$, respectively, corresponding to $96 \%$ COD removal, $44 \%$ sulfate removal and yielded about $24 \mathrm{~W} / \mathrm{m}^{2}$ power density. Further, MFC was fed with azo dye containing (50-1000 $\mathrm{mg} / \mathrm{L})$ simulated wastewater to evaluate dye removal performance of sulfate-reducing bacteria. Addition of azo dye slightly enhanced the power production to $26 \mathrm{~W} / \mathrm{m}^{2}$, the highest value obtained during our study. Sulfate and COD removals were adversely affected at azo dye concentrations over $300 \mathrm{mg} / \mathrm{L}$ and $150 \mathrm{mg} / \mathrm{L}$, respectively. Additionally, color removal performance of MFC was excellent however, chemical azo dye reduction out-competed with enzymatic reduction at high azo dye levels ( $>500 \mathrm{mg} / \mathrm{L}$ ) leading to a poor sulfate $(<15 \%)$ and COD $(<45 \%)$ removal and recovery of azo dye reduction efficiency to $91 \%$.

Keywords: Color, electricity generation, microbial fuel cell, sulfate.

\section{Introduction}

Microbial fuel cell (MFC) gained considerable interest in recent years for the applications of bioelectricity production along with simultaneous wastewater treatment (Sevda et al., 2013; Majumder et al., 2014). MFC is the device that uses bacteria as the catalysts in the anode to oxidize organic and inorganic matter. In general applications, MFC consists of anode and cathode chambers physically separated by a proton exchange membrane (PEM). Microorganisms attached on the biofilm layer of anode, oxidize organic matter anaerobically and then the electrons flow up from the anode onto the cathode through an external circuit, thus producing electricity (Guerrini et al., 2013). Additionally, the protons enter the cathode chamber where they combine with oxygen (terminal electron acceptor) to form water (Rabaey et al., 2007).

So far, simulated wastewaters containing diverse types of organic substrates and different kinds of wastewaters ranging from domestic wastewater to brewery wastewater (Wen et al., 2009) have been used as an energy source in MFC (Najafpour et al., 2010; Sharma and Li, 2010; Izadi and Rahimnejad, 2013). Additionally; previous MFC studies showed that the MFC can be also used for the treatment of biorefractory wastewater along with other degradable co-substrates (Su et al., 2013; Yong et al., 2014). One of most studied biorefractory compounds is azo dye characterized by $-\mathrm{N}=\mathrm{N}$ - which represents the largest class of dyes used in textileprocessing. Biodegradation of azo dyes is difficult due to their complex structure and synthetic nature, and hence these compounds are one of the most problematic contaminants in textile industry ( $\mathrm{Li}$ et al., 2016). However, previous studies showed that the azo bonds can be broken biologically by some anaerobes. The reduction of azo dyes under anaerobic condition is based on oxidation-reduction reactions in which the dye acts as the final electron acceptor while organic matter acts as the electron donor (Xu et al., 2016; Yang et al., 2016).

In this study, the azo dye and sulfate were selected as main contaminants. Sulfate largely presents in textile coloring wastewaters through its use in dye baths for ionic strength adjustment or as a leaving group from vinyl-sulphone reactive dye fixation onto cotton fibers (Albuquerque et al., 2005). Additionally, the use of $\mathrm{H}_{2} \mathrm{SO}_{4}$ in $\mathrm{pH}$ control provides an important contribution to sulfate availability. Several earlier studies investigated the possibility of MFCs for removal of azo dyes in simulated wastewater (Kong et al., 2013; Yong et al., 2014), however; there is a lack of information about the role of sulfate-reducing conditions on the azo dye reduction and 
electricity production in MFC. The biological sulfate reduction process is mediated by a group of microorganisms known as sulfate reducing bacteria (SRB) that use sulfate as electron acceptor. As anaerobic color removal occurs by the way of reduction of the azo dye which acts as a final electron acceptor in the microbial electron transport chain, color removal may be either stimulated or competitively suppressed in the presence of sulfate. Therefore, MFC was tested in the availability of sulfate and azo dye under different operating conditions to reveal the bioelectricity production of MFC by sulfate-reducing bacteria.

\section{Materials and methods}

\subsection{Simulated wastewater and inoculum source}

The MFC anode was inoculated with anaerobic sludge from a full-scale anaerobic digester located at Gaziantep, Turkey. The anode chamber was fed continuously with synthetic wastewater containing (per liter) $4 \mathrm{~g} \mathrm{NaHCO}_{3}$, $0.6 \mathrm{~g} \mathrm{NH}_{4} \mathrm{Cl}, 9.3 \mathrm{~g} \mathrm{NaH}_{2} \mathrm{PO}_{4} . \mathrm{H}_{2} \mathrm{O}, 3.2 \mathrm{~g} \mathrm{Na}_{2} \mathrm{HPO}_{4}, 0.125 \mathrm{~g}$ $\mathrm{K}_{2} \mathrm{HPO}_{4}, 0.11 \mathrm{~g} \mathrm{CaCl} 2.2 \mathrm{H}_{2} \mathrm{O}, 0.5 \mathrm{~g}$ cyctein $\mathrm{HCl}$, minor amounts of metal ions ( $\mathrm{Fe}, \mathrm{Zn}, \mathrm{Co}, \mathrm{Cu}, \mathrm{Mn}$ and $\mathrm{Ni}$ ) and vitamins. Acetate, contributed to $1000 \mathrm{mgCOD} / \mathrm{L}$, was used to provide a readily biodegradable carbon source for MFC. Both magnesium sulfate and sodium sulfate were used as sulfate source. The studied azo dye was the monoazo reactive dye Remazol Brilliant Violet $5 R$ (C.I Reactive Violet 5), (Sigma-Aldrich, Germany). The synthetic wastewater was prepared daily.

\subsection{Microbial fuel cell design and operation}

Schematic views and photograph of the dual-chamber MFC used in the experiments are shown in shown in Figure $1 \mathrm{~A}$ and $1 \mathrm{~B}$, respectively.

The technical characteristic and operation procedures of the MFC are the same as previously used MFC (Cirik, 2014). The electrode was Pt (effective surface area for biofilm growth was $32 \mathrm{~cm}^{2}$ ), which has been widely used in MFC technology. In order to minimize the internal resistance involved with ohmic loses, both electrodes were placed in direct contact with the proton exchange membrane. The electrodes were connected with copper wire through a resistance of $10 \Omega$ during the experiment.

The synthetic wastewater was continuously pumped into the anode chamber using a peristaltic pump (Masterflex L/S, Cole-Parmer 7524-45, USA). The anode chamber was sparged with nitrogen to remove oxygen to ensure anaerobic condition during the MFC operation. All experiments were carried out at uncontrolled $\mathrm{pH}$ and the constant temperature of $30 \pm 2^{\circ} \mathrm{C}$. The cathode chamber was aerated continuously using air pumps to provide oxygen as the terminal electron acceptor.

The performance of the MFC was evaluated for around 570 days in three different parts (Table 1). Optimization of sulfate-reducing conditions in the MFC system was performed in the first two parts, while the last part mainly related to the azo dye reduction studies under sulfate-reducing conditions. The operational conditions were changed after observing steady state measurements in $C O D$, sulfate and azo dye concentrations.

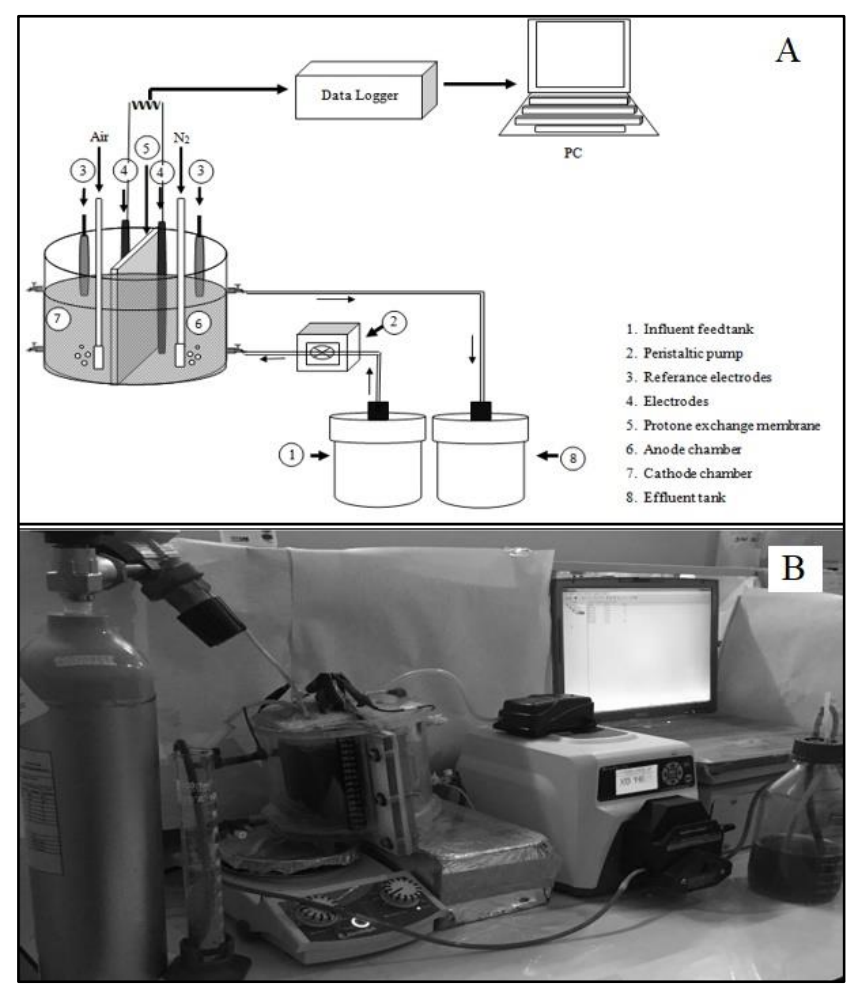

Figure 1. Schematic view of dual-chamber MFC (A), Photograph of the dual-chamber MFC used in the experiments (anode chamber on the left; cathode chamber on right) (B)

The details of each partare shown in Table 1 . In the first part (days 0-133), the effect of varying COD/sulfate ratio(10-1.11) was evaluated at constant HRT of 24 hours. During part II (days 158-267), HRT was increased stepwise from $12 \mathrm{~h}$ to $48 \mathrm{~h}$ at optimum COD/sulfate ratio of 1.66 . In the last part of the study, Remazol Brilliant Violet 5R (C.I Reactive Violet 5) (Sigma-Aldrich, Germany) was included to the feed solution to provide influent azo dye concentrations of 50-1000 mg/L. The reactor was sampled 3 times a week for performance evaluation. All assays were run in triplicate and mean values were presented.

\subsection{Analyses}

Samples were firstly filtered through a pre-washed filter paper through $0.45 \mu \mathrm{m}$ pore-sized syringe filter (Sartorius AG, Gottingen, Germany) to remove biomass and other particles. Azo dye concentrations were measured spectrophotometrically with a Shimadzu UV-1601 Spectrophotometer at $560 \mathrm{~nm}$ using the experimentally derived calibration curve $\left(\mathrm{ABS}_{560 \mathrm{~nm}}=0.0138^{*}\right.$ Conc. azodye + 0.005; $\left.R^{2}=0.9999\right)$. Intermediates of $R B V-5 R$ were analyzed using an HPLC system equipped with SPD-M20A diode array detector (DAD) (Shimadzu Co. Kyoto, Japan) and Inertsil ODS-3V (250 mm × $4.6 \mathrm{~mm}$ ID $5 \mu \mathrm{m})$ column. 
Table 1. Operational conditions of MFC

\begin{tabular}{|c|c|c|c|c|c|c|c|}
\hline Parts & Periods & Days & $\operatorname{COD}(\mathrm{mg} / \mathrm{L})$ & Sulfate $(\mathrm{mg} / \mathrm{L})$ & COD/sulfate ratio & HRT (hour) & Azo dye $(\mathrm{mg} / \mathrm{L})$ \\
\hline \multirow{4}{*}{$\begin{array}{c}\text { Part } 1 . \\
\text { Effect of } \\
\text { COD/Sulfate ratio }\end{array}$} & 1 & \multirow{4}{*}{$(0-133)$} & \multirow{4}{*}{1000} & 100 & 10 & \multirow{4}{*}{24} & \multirow{4}{*}{-} \\
\hline & ॥ & & & 300 & 3.33 & & \\
\hline & III & & & 600 & 1.66 & & \\
\hline & IV & & & 900 & 1.11 & & \\
\hline \multirow{4}{*}{$\begin{array}{c}\text { Part } 2 . \\
\text { Effect of HRT }\end{array}$} & 1 & \multirow{4}{*}{$(158-267)$} & \multirow{4}{*}{1000} & \multirow{4}{*}{600} & \multirow{4}{*}{1.66} & 12 & - \\
\hline & II & & & & & 24 & - \\
\hline & III & & & & & 36 & - \\
\hline & IV & & & & & 48 & - \\
\hline \multirow{8}{*}{$\begin{array}{c}\text { Part } 3 . \\
\text { Effect of azo dye } \\
\text { concentration }\end{array}$} & 1 & \multirow{8}{*}{$(317-569)$} & \multirow{8}{*}{1000} & \multirow{8}{*}{600} & \multirow{8}{*}{1.66} & \multirow{8}{*}{36} & 50 \\
\hline & ॥ & & & & & & 100 \\
\hline & III & & & & & & 150 \\
\hline & IV & & & & & & 200 \\
\hline & $\mathrm{V}$ & & & & & & 300 \\
\hline & VI & & & & & & 500 \\
\hline & VII & & & & & & 750 \\
\hline & VIII & & & & & & 1000 \\
\hline
\end{tabular}

Aromatic amine standards were generated with the use of sodium dithionite $\left(\mathrm{Na}_{2} \mathrm{~S}_{2} \mathrm{O}_{4}\right)$ for the cleavage of the $-\mathrm{N}=\mathrm{N}-$ linkage followed by HPLC analysis of the reduction products of RBV-5R. Chemical reduction was performed for $5 \mathrm{~min}$ at $70^{\circ} \mathrm{C}$ with a dithionite/color (w:w) ratio of 10. Dissolved sulfide concentration was determined with the use of a Shimadzu UV-1601 Spectrophotometer. COD and alkalinity were determined according to APHA standard methods (APHA, 1999). Samples were acidified with concentrated $\mathrm{H}_{2} \mathrm{SO}_{4}$ to below $\mathrm{pH} 2$ and purged with $\mathrm{N}_{2}$ gas for approximately $5 \mathrm{~min}$ to remove $\mathrm{H}_{2} \mathrm{~S}$ prior to $\mathrm{COD}$ determination. An ion chromatography (Dionex ICS-3000, Sunnyvale, CA, USA) equipped with Ion Pac AG19 guard and AS19 analytical columns were used to measure the sulfate concentrations. The $\mathrm{pH}$ of each chamber was measured using multimeter (WTW340I Weilheim, Germany). The ORP level between anode and cathode compartments was measured by $\mathrm{Ag} / \mathrm{AgCl}$ reference electrode (BASI, MF-2052). The voltage (V) across an external resistance (10 $\Omega$ ) in the MFC circuit was on-line monitored at 60-min intervals using an online data acquisition system.

\subsection{Calculations}

Voltage data acquisition from MFC was conducted using a Fatek programmable controller data logging system. The current (I) flowing through the external circuit was calculated using the Ohm's law, where $\mathrm{V}$ is the measured voltage, and $\mathrm{R}$ (ohm) is the external resistance (Eq. 1).

$$
\mathrm{I}(A)=\frac{\mathrm{V}}{\mathrm{R}}
$$

Measured electrical voltage across the load and the current converted to power, $\mathrm{P}$ (watt), according to (Eq. 2).

$P($ watt $)=V . I=I^{2} \cdot R$

Power density, $P_{A n}\left(W / m^{2}\right)$, was normalized by the crosssectional area of the studied electrode in the anode chamber.
Coulombic efficiency reflects the ratio of the number of electrons passing through the external load, which generates electricity, to the number of electrons removed from the substrate during bio conversion. The coulombic efficiency $(\eta \mathrm{CE})$ of continuous flow MFC was calculated as follows (Eq. 3) (Liu and Logan, 2004):

$$
\eta \mathrm{CE}=\frac{\mathrm{I}}{\mathrm{F} \cdot\left(\frac{4}{32}\right) \cdot \Delta \operatorname{COD} \cdot \mathrm{Q}_{\text {in }}}
$$

where $\mathrm{I}$ is the current $(\mathrm{A}), \mathrm{F}$ is the Faraday constant $\left(96.485 \mathrm{C} / \mathrm{mol}^{-} \mathrm{e}^{-}\right), 4$ is the electron number gained by the reduction reaction of $1 \mathrm{M} \mathrm{O}_{2}, 32$ is the molar mass of $\mathrm{O}_{2}$, $\mathrm{Q}_{\text {in }}$ is volumetric influent flow rate of MFC (L/s), $\triangle C O D$ is the difference of chemical oxygen demand (COD) between influent and effluent.

\section{Results and discussion}

\subsection{Effect of COD/sulfate ratio on MFC performance}

This part of the study was composed of four periods in which MFC was fed with azo dye free wastewater to enrich acetate-oxidizing sulfate-reducing bacteria (SRB) at varying COD/sulfate ratios. Normally, sulfate is biologically reduced under anaerobic conditions and eight electrons are used to produce sulfide while acetate is oxidized to carbon dioxide as shown in the following reactions (Eqs. 4-6):

$\mathrm{CH}_{3} \mathrm{COO}^{-}+2 \mathrm{H}_{2} \mathrm{O} \rightarrow 2 \mathrm{CO}_{2}+8 \mathrm{e}^{-}+7 \mathrm{H}^{+}$

$\mathrm{SO}_{4}{ }^{2-}+10 \mathrm{H}^{+}+8 \mathrm{e}^{-} \rightarrow \mathrm{H}_{2} \mathrm{~S}+4 \mathrm{H}_{2} \mathrm{O}$

$\mathrm{CH}_{3} \mathrm{COO}^{-}+\mathrm{SO}_{4}{ }^{2-}+3 \mathrm{H}^{+} \rightarrow 2 \mathrm{CO}_{2}+\mathrm{H}_{2} \mathrm{~S}+2 \mathrm{H}_{2} \mathrm{O}$

According to the above reactions, stoichiometric value for sulfate reduction is equal to COD/sulfate ratio of 0.67 which is lower than COD/sulfate ratios used in this study. It should be noted that there was no apparent carbon limitation for sulfate reduction in MFC reactor. 
The value of 0.67 is recommended as adequate for SRB, while a higher ratio than 2.7 is favorable to methane-producing bacteria (Chen and Cheng, 2008).

To evaluate the effect of COD/sulfate ratio on reactor performance the influent COD was kept constant at $1000 \mathrm{mg} / \mathrm{L}$ and sulfate concentration in the feed was increased stepwise from $100 \mathrm{mg} / \mathrm{L}$ to $900 \mathrm{mg} / \mathrm{L}$, corresponding to COD/sulfate ratio of 10-1.1 (Table 1 ). The COD removal, bioelectricity production and sulfate removal performances of MFC system are shown in Figure $2 A, B$ and $C$, respectively. In the first period, MFC was operated at $\mathrm{COD} /$ sulfate ratio of 10 , corresponding to $1000 \mathrm{mg} / \mathrm{L}$ and $100 \mathrm{mg} / \mathrm{L}$ influent COD and sulfate concentrations, respectively. Sulfate and COD removal efficiencies were about $48 \%$ and $74 \%$, and bioelectricity production was $25 \mathrm{~W} / \mathrm{m}^{2}$ during the first period (Figure 2). Dissolved sulfide was observed about $10 \mathrm{mg} / \mathrm{L}$ in the effluent. Increase in influent sulfate concentration to 300 $\mathrm{mg} / \mathrm{L}$ (Period II) and $600 \mathrm{mg} / \mathrm{L}$ (Period III), corresponding to $\mathrm{COD} /$ sulfate ratio to 3.3 and 1.66 , respectively; had a positive effect on COD removal efficiency which was approached to $90 \%$ and $98 \%$, respectively. However, further decrease in $\mathrm{COD} /$ sulfate ratio to 1.1 in the last period (Period IV) did not change COD removal efficiency, which was about $98 \%$ (Figure 2A). Although COD in the feed was always higher than the stoichiometric requirement (COD/sulfate $=0.67)$, sulfate removal efficiency decreased to $40 \%, 35 \%$, and $24 \%$ in periods II, III and IV when sulfate concentration in the feed was increased to $300 \mathrm{mg} / \mathrm{L}, 600 \mathrm{mg} / \mathrm{L}$, and $900 \mathrm{mg} / \mathrm{L}$, respectively. In this study, $\mathrm{COD} /$ sulfate ratio of 1.66 was found optimum in terms of high COD removals (98\%) and bioelectricity production. In a study performed by Ghangrekar et al. (2010) obtained lower COD removal compared to our study which was about $79 \%$ at the COD/sulfate ratio of 0.8 .

The COD removal in subsequent period (period IV) was similar however, energy production was lower. Sulfide production in the first period was low being $10 \mathrm{mg} / \mathrm{L}$ but then gradually increased parallel to decreased COD/sulfate ratio and reached to $18 \mathrm{mg} / \mathrm{L}, 25 \mathrm{mg} / \mathrm{L}$, $30 \mathrm{mg} / \mathrm{L}$, in periods II, III and IV, respectively, supporting sulfate removal data (Figure $2 \mathrm{C}$ ). The predominant sulfur compound was $\mathrm{HS}$ at the $\mathrm{pH}$ levels in the anode compartment (8.0-8.5). However, there was a discrepancy in the balance of sulfur compounds between the amount of sulfate removed and sulfide generated. Possibility of sulfide diffusion toward the cathode compartment was eliminated by proton exchange membrane since sulfide was not detected in cathode effluent. Previous studies demonstrated that produced sulfide could be oxidized at the anode to elemental sulfur, thiosulfate or sulfate (Sun et al., 2010; Lee et al., 2012). Elemental sulfur $\left(S^{0}\right)$ formation observed during MFC operation confirmed the sulfide oxidation and part of sulfide loss can be explained by such a mechanism.
The bioelectricity production went up with the rise of influent sulfate concentration from $100 \mathrm{mg} / \mathrm{L}$ (Period I) to $300 \mathrm{mg} / \mathrm{L}$ (Period II), which was increased from $25 \mathrm{~W} / \mathrm{m}^{2}$ to $27 \mathrm{~W} / \mathrm{m}^{2}$, respectively (Figure $2 \mathrm{~B}$ ). However, further increase in influent sulfate concentration adversely affected the bioelectricity generation, which dropped to $23 \mathrm{~W} / \mathrm{m}^{2}$ and $22 \mathrm{~W} / \mathrm{m}^{2}$ in periods III and IV, respectively. The power density obtained in our study was relatively higher compared to previous studies (Zhao et al., 2009; Ghangrekar et al., 2010).

Anode alkalinity is produced as a result of sulfate reduction coupled with organic carbon oxidation (Eqs. 4-6) (Ozdemir et al., 2013). The alkalinity production in the anode was about $877 \mathrm{mgCaCO}_{3} / \mathrm{L}$ at period I. In subsequent periods, alkalinity production slightly decreased to 780,770 , and $765 \mathrm{mgCaCO}_{3} / \mathrm{L}$ in periods II, III, and IV, respectively. This was due to the increased carbon dioxide production since COD removals were higher in these periods. Conversely, cathode influent $\mathrm{pH}$ of 6.85 decreased slightly to 6.68 during MFC operation. This was due to the movement of $\mathrm{H}^{+}$ions from the anode to cathode, which is typically observed in an MFC. Coulombic efficiency $(\in C)$ was the fraction of electrons (charge) that contribute to electricity generation and affected from the anode feed exists in the MFC system.

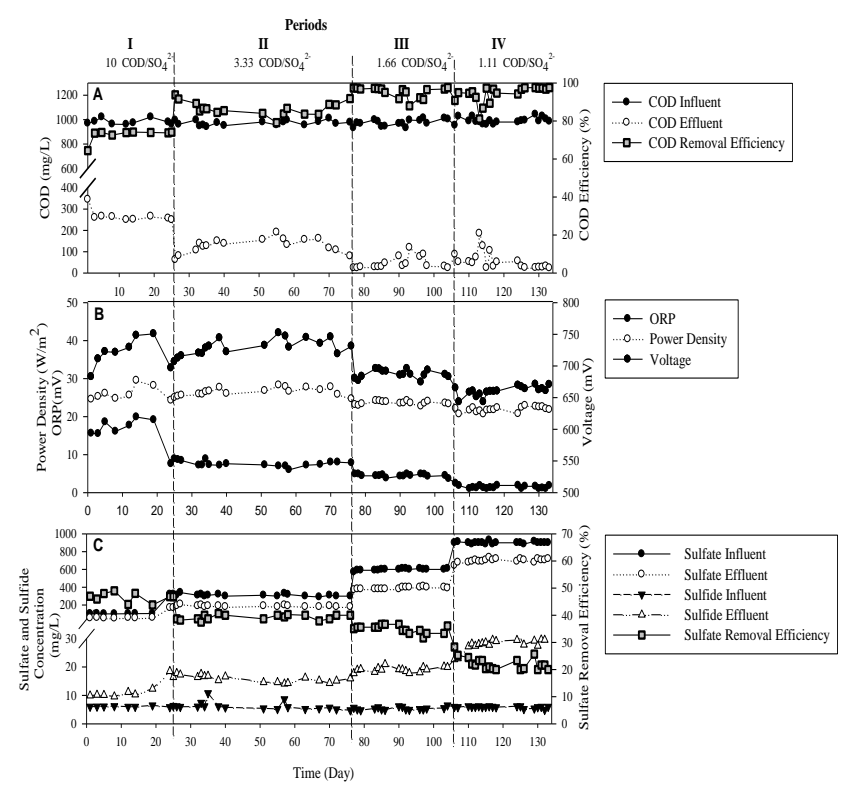

Figure 2. COD removal (A), voltage-power generation (B), and sulfate-sulfide profiles (C) observed in dual-chamber MFC

Generally, the observed EC values in MFCs inoculated with mixed cultures and operated with real wastewater were relatively lower compared to simulated wastewaters (Lefebvre and Al-Mamun, 2008). In our study, coulombic efficiency was $18 \%$ in the first period and decreased to 15.3 ; 12.8 ; and $12.5 \%$ when feed sulfate concentration increased from 100 to 300,600 , and $900 \mathrm{mg} / \mathrm{L}(10 \Omega)$, in periods II, III, and IV; respectively. Similarly, in a study 
performed by Zhao et al. (2018), obtained EC values was between $10.0-12.5 \%$.

\subsection{Effect of HRT on MFC performance}

HRT was increased stepwise from $12 \mathrm{~h}$ to $48 \mathrm{~h}$ at optimum $\mathrm{COD} /$ sulfate ratio of 1.66 obtained from the first part of the study. Additionally, COD and sulfate concentrations were kept constant at $1000 \mathrm{mg} / \mathrm{L}$ and $600 \mathrm{mg} / \mathrm{L}$ during this study part, respectively.

In the first period, continuously-fed MFC was operated with HRT of $12 \mathrm{~h}$ and COD removal efficiency was reached to $79 \%$ (Figure $3 \mathrm{~A}$ ). Produced sulfide concentration as a result of biological sulfate reduction was around $18.8 \mathrm{mg} / \mathrm{L}$ and the maximum sulfate removal observed in this period was about $26 \%$, which indicated that the HRT remained inadequate for sulfate reduction activity, corresponding to $445 \mathrm{mg} / \mathrm{L}$ effluent sulfate concentration (Figure 3C). Additionally, the maximum power density of $21 \mathrm{~W} / \mathrm{m}^{2}$ was obtained in this study period, corresponding to a cell voltage of $640 \mathrm{mV}$ (Figure 3B). In the subsequent two periods (period II and III), HRT was increased stepwise to $24 \mathrm{~h}$ and $36 \mathrm{~h}$, respectively. In these periods, COD removal efficiency prominently increased and reached around $96 \%$, corresponding to effluent COD concentration of around $30 \mathrm{mg} / \mathrm{L}$ (Ge et al., 2013). The increasing HRT from $12 \mathrm{~h}$ to $24 \mathrm{~h}$ and $36 \mathrm{~h}$ slightly increased cell voltage which approached to $675 \mathrm{mV}$ and $690 \mathrm{mV}$, respectively. The maximum power density of $24 \mathrm{~W} / \mathrm{m}^{2}$ was obtained in the period III at HRT of $36 \mathrm{~h}$. The results indicated that high HRT was in favour of increasing power generation in dual-chamber MFC and the HRT of $36 \mathrm{~h}$ was found optimum for high MFC performance.

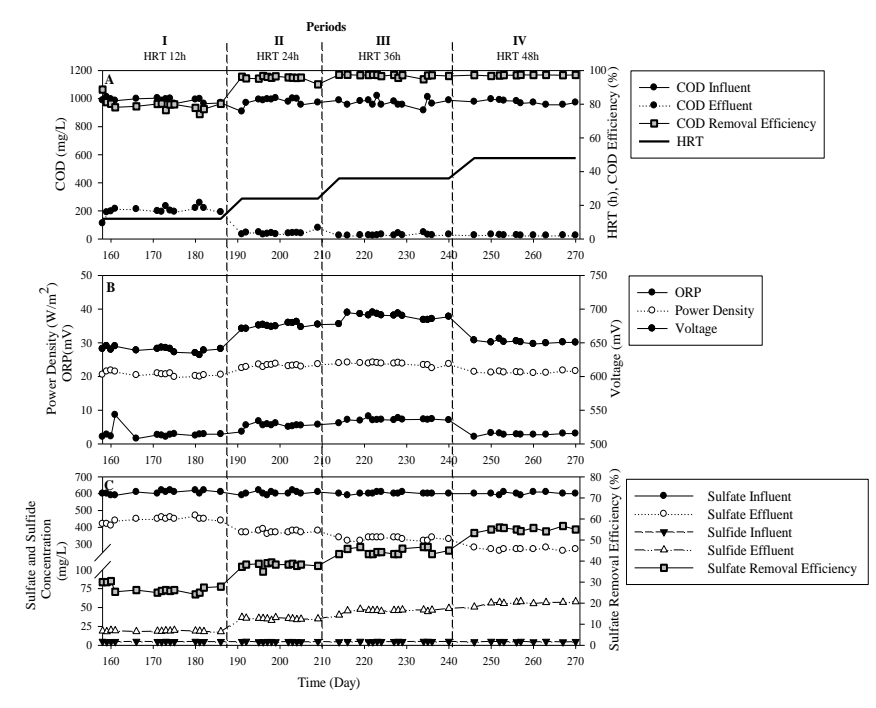

Figure 3. COD removal (A), voltage-power generation (B), and sulfate-sulfide profiles (C) observed in dual-chamber MFC

Additionally, the increase in the bioelectricity production was due to the sufficient contact time between electron donor and bacteria related to high HRT (Figure $3 \mathrm{~A}$ and $3 \mathrm{~B}$ ). When HRT was increased to $24 \mathrm{~h}$ and $36 \mathrm{~h}$, sulfate removal increased and reached to $38 \%$ and $44 \%$ in the periods II-III, respectively. Dissolved sulfide concentration incrementally reached to $35.2 \mathrm{mg} / \mathrm{L}$ and $46.9 \mathrm{mg} / \mathrm{L}$, respectively. In the last period, MFC was operated at HRT of 48 h. Significant variation in the effluent COD concentration was not observed compared to period III, corresponding to $27 \mathrm{mg} / \mathrm{L}$ and $97.2 \%$ removal efficiencies respectively. Increasing HRT resulted in improvement of sulfate removal efficiency which was $55 \%$ in period IV (Figure 3C). The increase sulfate profile can be explained that microorganisms responsible for anaerobic sulfate reduction has a relatively low growth rate, and thus long HRT level was increased microbial activity of SRB (Cirik et al., 2013). Sulfate removal and sulfide generation had a similar profile and compatible with each other. Sulfide production in the anode chamber of MFC reached to $60 \mathrm{mg} / \mathrm{L}$, supporting sulfate removal data in the last period (Figure 3C). Very high HRT levels ( $\geq 48 \mathrm{~h}$ ) adversely affected MFC performance in terms of bioelectricity generation and power density, which was decreased from $24 \mathrm{~W} / \mathrm{m}^{2}$ to $21 \mathrm{~W} / \mathrm{m}^{2}$ (Figure 3B). Coulombic efficiency observed in our study was $7.4 \%$ in the first period and increased to 13 , and $17.3 \%$ when HRT increased from $12 \mathrm{~h}$ to $24 \mathrm{~h}$, and $36 \mathrm{~h}$, in periods II, and III, respectively. The maximum coulombic efficiency of $24 \%$ was obtained in the last period at HRT of $48 \mathrm{~h}$.

Acetate oxidation, sulfate reduction, and proton exchange membrane properties are the main factors responsible for variance in $\mathrm{pH}$ and alkalinity. $\mathrm{pH}$ increment was observed as a result of sulfate reduction coupled with organic carbon oxidation. Additionally, the formation of organic acids and releasing of hydrogen ions during the anodic reaction (organic matter fermentation) decreased $\mathrm{pH}$ value in the anode chamber (Akman et al., 2013; Akman et al., 2014). Anode influent $\mathrm{pH}$ value was kept constant at 5.1 throughout the MFC operation. $\mathrm{pH}$ tended to increase at the first two periods and this increment was probably resulted from increasing sulfate removal efficiency at high HRT levels (Figure $3 C$ ). However, the significant increase in $\mathrm{pH}$ value was never observed in the periods III and IV, although sulfate removal efficiency was higher than other periods (period I and II) as a result of high performance of the proton exchange membrane (high proton diffusion rate through the membrane). Anode alkalinity values gradually increased from 624 $\mathrm{mgCaCO}_{3} / \mathrm{L}$ to $757 \mathrm{mgCaCO}_{3} / \mathrm{L}$ during all periods (periods I-IV) as a result of sulfate reduction and simultaneous organic carbon oxidation in the anode chamber. Influent cathode $\mathrm{pH}$ value was about 6.85. Effluent $\mathrm{pH}$ and alkalinity values of the cathode chamber were not affected from varying HRT due to the daily change with distilled water of the cathode content, corresponding to $6.5 \mathrm{pH}$ and $10.5 \mathrm{mgCaCO}_{3} / \mathrm{L}$ alkalinity.

\subsection{Effect of azo dye concentration on MFC performance}

In this part of the study, MFC was operated under sulfatereducing conditions at different initial dye concentrations (50-1000 mg/L). COD/sulfate ratio was 1.66 (Table 1 ). Additionally, HRT was kept constant at $36 \mathrm{~h}$ during study periods. The profiles of COD, sulfate, azo dye removal and bioelectricity production were shown in Figure 4 . 


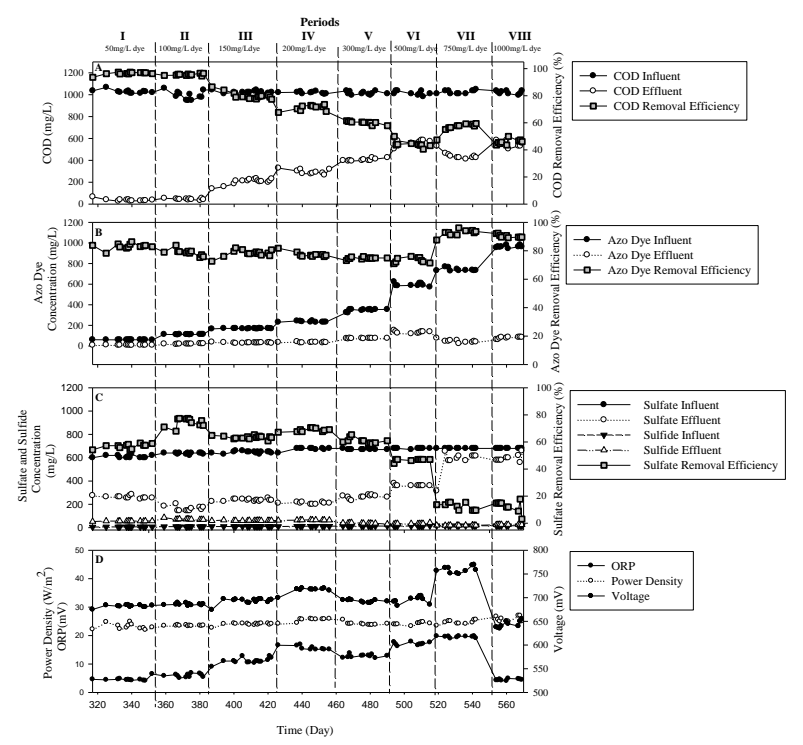

Figure 4. COD removal (A), azo dye concentration (B), sulfatesulfide profiles (C) and voltage-power generation (D) observed in dual-chamber MFC

Since anaerobic azo dye reduction is an oxidationreduction reaction, a liable electron donor is essential to achieve high color removal rates. Acetate in the synthetic wastewater acted electron donor source for both sulfate and azo dye reductions, corresponding to $1000 \mathrm{mg} / \mathrm{L}$ influent COD. COD removal was $96 \%$ in the first period and decreased when influent azo dye concentration was increased. The observed COD removals in periods II-VIII were $95,80,71,60,44,56$, and $45 \%$, respectively (Figure 4A).

As azo bond cleavage $-\mathrm{N}=\mathrm{N}-$ involves a transfer of four-electrons (reducing equivalents), one-mole azo dye equals to $32 \mathrm{gCOD}$, corresponding to $0.043 \mathrm{gCOD} / \mathrm{g}$ azo dye (RBV-5R). Hence, the COD requirement for azo dye reduction even at the highest azo dye concentration (1000 mg/L) was calculated as $43 \mathrm{mgCOD} / \mathrm{L}$. Some proportion of the substrates could be consumed for azo dye reduction, however, for a real perspective application, the COD demand of azo dye reduction to be negligible, and therefore there may be different factors responsible for decreasing COD removal efficiencies. One could be due to the toxic effects of azo dye and its breakdown products on the microorganism, another could be due to the aromatic amines that form due to cleavage of the $-\mathrm{N}=\mathrm{N}-$ bond of $\mathrm{RBV}-5 \mathrm{R}$ contributed the residual COD, resulting in low COD removals.

The variations of azo dye concentrations in the sulfate-reducing MFC are presented in Figure 4B. In the first period dye removal efficiency was $83 \%$ and decreased linearly proportional to increased influent dye concentration during periods II, III, IV, V, and VI corresponding to $78.8 ; 78.2 ; 76 ; 74.8$; and $73.5 \%$ dye removal efficiencies; respectively. However, further increase in dye concentrations to $1000 \mathrm{mg} / \mathrm{L}$; an unexpected improvement on dye removal was observed, corresponding to 92 and $91 \%$ azo dye removal efficiency which was similar to previously published studies (Marin et al., 2018; Sun et al., 2009). The high azo dye reduction by SRB may occur enzymatically or chemically with the sulfide produced during dissimilatory sulfate reduction. There may be two processes in this study responsible for azo dye removal: (i) chemical reduction by biologically produced sulfide and (ii) enzymatic reduction. In enzymatic azo dye reduction both influent COD (organic matter) and azo dye are expected to be reduced simultaneously, therefore chemical reduction seems dominant mechanism responsible for azo dye reduction as COD removal was relatively dropped.

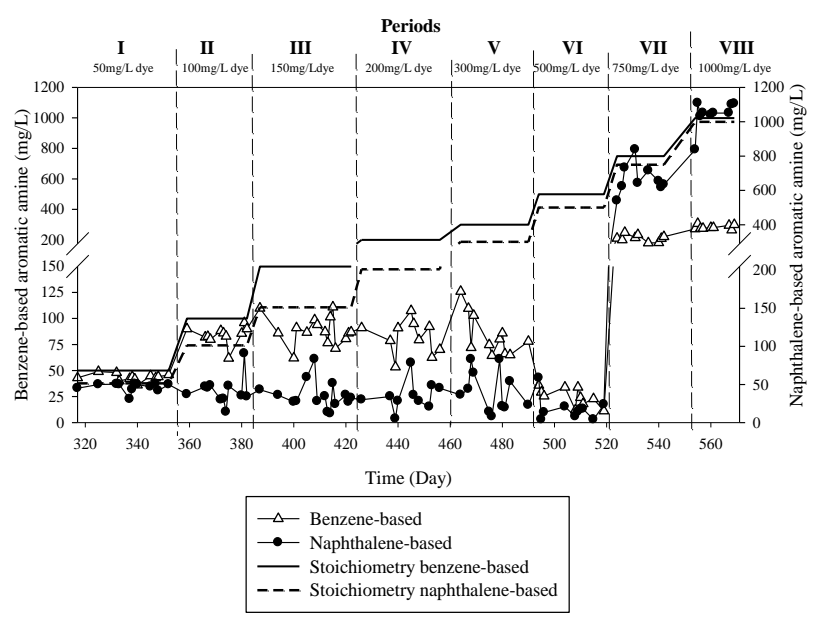

Figure 5. Benzene and naphthalene-based aromatic amine profiles observed in dual-chamber MFC

Sulfate removal was initially increased from 56 to $74 \%$ by increasing influent azo dye to $100 \mathrm{mg} / \mathrm{L}$ (period II) however it decreased stepwise and dropped to $12 \%$ when influent azo dye concentration was $1000 \mathrm{mg} / \mathrm{L}$ which was the maximum azo dye concentration tested during this study (period VIII). Considering that the required amount of organic matter for azo dye reduction was quite lower than that for sulfate reduction, which was discussed above, the decrease of sulfate reduction should be due to toxic effects of azo dyes and breakdown products on the microorganism. Sulfide productions were parallel to sulfate removals supporting sulfate removal data (Figure 4C), however discrepancy in the balance of dissolved sulfide and reduced sulfate were again observed. The observed elemental sulfur was the main reason as discussed above. Similarly, Zhang et al. (2008), proposed the possibility to utilize the sulfate-reducing bacteria to convert sulfate to sulfide, then the MFC to convert the formed sulfide to elementary sulfur. Electricity production was slightly accelerated however it was relatively stable about $24-26 \mathrm{~W} / \mathrm{m}^{2}$ compared to other operational parameters. Coulombic efficiency $(10 \Omega)$, was $17.2 \%$ in the first period and increased to $17.6 ; 21 ; 24.9 ; 28 ; 38 ; 33 ; 34 \%$ when feed azo dye concentration increased from 50 to 100, 150, 200, 300, 500, 750 and $1000 \mathrm{mg} / \mathrm{L}$ in periods II-VIII; respectively. As a result, increasing dye concentration increased the recovery of electrons. However, after dye concentration was increased to $1000 \mathrm{mg} / \mathrm{L}$, the voltage generation was decreased from $700-780 \mathrm{mV}$ to $650 \mathrm{mV}$. Similar results were reported by Marin et al. (2018). The chemically 
reduced Remazol Brilliant Violet $5 \mathrm{R}$ products were used as aromatic amine standard due to the unavailability of true standards. There were two main peaks in HPLC measurements corresponding to the benzene-based and naphthalene based aromatic amines. An examination of the HPLC analyses results in Figure 5 reveals that the formation of aromatic amines indicates azo dye reduction. This suggests that bacterial cultures can reduce azo dyes and produce aromatic amines at sulfate reducing conditions. Stoichiometric values of formed products for each azo dye concentration applied were also added. Actually, accumulation of aromatic amines was expected since they are generally persisted to anaerobic conditions and tend to accumulate to toxic levels (Yasar et al., 2012). However, aromatic amine concentrations were always below stoichiometric values reflecting the removal of aromatic amines by attached anaerobes on sulfate reducing anodic electrode. It seems that this attached growth provides the biological removal of aromatic amines by facilitating the growth of specific microorganisms in high sludge ages which is in favor of low growing rate microorganism. There are few reports in literature related to aromatic amine degradation under sulfate reducing conditions. Increase in azo dye concentration resulted in increased aromatic amine removal. Benzene based aromatic amine removal was $13 \%$ in the period $\mathrm{I}$ and reached to $95 \%$ in periods $\mathrm{VI}$. Similarly, naphthalene based aromatic amine removal was $97 \%$ in period VI. However, between days 520 and 569 (period VII-VIII), increased aromatic amine formation was observed rather than removal especially for naphthalenebased amine (Figure 5). This was probably due to the toxic effect of azo dye on microorganism since in these periods (VII and VIII) all biological parameters were fallen down. Alkalinity production was lower compared to previous parts and tended to decrease as dye loading was increased. Alkalinity production in period I was 637 $\mathrm{mgCaCO}_{3} / \mathrm{L}$ at $50 \mathrm{mg} / \mathrm{L}$ dye concentration then dropped to $478 \mathrm{mgCaCO}_{3} / \mathrm{L}$ in period VIII. The effluent $\mathrm{pH}$ of the anode (periods I-VI) was close to 8.0-8.6 throughout the reactor operation although the feed $\mathrm{pH}$ was relatively low as 5.1. However, lower $\mathrm{pH}$ values observed in periods VII and VIII were probably due to the adverse effect of dye on microorganism activity.

\section{Conclusion}

In this study, the sulfate reducing MFC system has been successfully operated for simultaneous sulfate and dye removal. Under dye free conditions optimum COD/sulfate ratio and HRT were 1.66 and $36 \mathrm{~h}$, respectively; corresponding to $96 \%$ COD, $44 \%$ sulfate removal and yielded about $24 \mathrm{~W} / \mathrm{m}^{2}$ power density. MFC was successful for simultaneous reduction of sulfate and azo dye. Surprisingly $97 \%$ removal of break down products was achieved by sulfate reducing anaerobes. High azo dye concentrations (>500 $\mathrm{mg} / \mathrm{L}$ ) adversely affected biological parameters (COD, sulfate and aromatic amine), while dye removal and power density reached to highest values of $92 \%$ and $26 \mathrm{~W} / \mathrm{m}^{2}$, respectively.

\section{References}

Akman D., Cirik K., Ozdemir S., Ozkaya B., Cinar O. (2013), Bioelectricity generation in continuously-fed microbial fuel cell: Effects of anode electrode material and hydraulic retention time, Bioresource Technology, 149, 459-464.

Akman D., Ozdemir S., Cirik K., Ozkaya B., Cinar O. (2014), Effect of some operational parameters in fed-batch microbial fuel cells for electricity generation. Research Journal of Chemistry and Environment, 18(3), 87-93.

Albuquerque M.G.E., Lopes A.T., Serralheiro M.L. (2005), Biological sulphate reduction and redox mediatör effects on azo dye decolourisation in anaerobic-aerobic sequencing batch reactors. Enzyme and Microbial Technology, 36, 790-799.

APHA (1999), Standard Methods for the Examination of Water and Wastewater, 20th ed., American Public Health Association/American Water Works Association/Water Environment Federation, Washington, DC, USA.

Chen Y., Cheng J.J., Creamer K.S. (2008), Inhibition of anaerobic process: a review. Bioresource Technology 99, 4044-4046.

Cirik K., Dursun N., Sahinkaya E., Cinar O. (2013), Effect of electron donor source on the treatment of $\mathrm{Cr}(\mathrm{VI})$-containing textile wastewater using sulfate-reducing fluidized bed reactors (FBRs). Bioresource Technology 133, 414-420.

Cirik K. (2014), Optimization of bioelectricity generation in fed-batch microbial fuel cell: effect of electrode material, initial substrate concentration, and cycle time. Applied Biochemistry and Biotechnology, 173(1), 205-214.

Ge Z., Ping Q., Xiao L., He Z. (2013), Reducing effluent discharge and recovering bioenergy in an osmotic microbial fuel cell treating domestic wastewater. Desalination 312, 52-59.

Ghangrekar M.M., Murthy S.S.R., Behera M., Duteanu N. (2010), Effect of sulfate concentration in the wastewater on microbial fuel cell performance. Environmental Engineering and Management Journal, 9, 1227-1234.

Guerrini E., Cristiani P., Trasatti S.P.M. (2013), Relation of anodic and cathodic performance to $\mathrm{pH}$ variations in membraneless microbial fuel cells. International Journal of Hydrogen Energy, 38(1), 345-353.

Izadi P., Rahimnejad M. (2013), Simultaneous electricity generation and sulfide removal via a dual chamber microbial fuel cell. Biofuel Research Journal 1, 34-38.

Kong F.Y., Wang A.J., Liang B., Liu W.Z., Cheng H.Y. (2013), Improved azo dye decolorization in a modified sleeve-type bioelectrochemical system. Bioresource Technology 143, 669-673.

Lefebvre O., Al-Mamun A., Ng H.Y. (2008), A microbial fuel cell equipped with a biocathode for organic removal and denitrification. Water Science \& Technology 58, 881-885.

Li Y., Yang H., Shen J., Mu Y., Yu H. (2016), Enhancement of azo dye decolourizationina MFC-MEC coupled system. Bioresource Technology, 202, 93-100.

Majumder D., Maity J.P., Tseng M.J., Chen H.R., Chen C.C., Chang Y.F., Yangand T.C., Chenet C.Y. (2014), Electricity generation and wastewater treatment of oil refinery in microbial fuel cells using Pseudomonasputida. International Journal of Molecular Sciences, 15, 16772-16786.

Marin W., Jang J., Nawaz M., Shahzad A., Lee D.S. (2018), Sulfate-reducing mixed communities with the ability to generate bioelectricity and degrade textile diazo dye in 
microbial fuel cells. Journal of Hazardous Materials, 352, 70-79.

Najafpour G., Rahimnejad M., Mokhtarian M., Ramli W.D., Ghoreyshi A. (2010), Bioconversion of whey to electrical energy in a biofuel cell using Saccharomyces cerevisiae. World Applied Sciences Journal, 8, 1-5.

Ozdemir S., Cirik K., Akman D., Sahinkaya E., Cinar O. (2013), Treatment of azo dye-containing synthetic textile dye effluent using sulfidogenic anaerobic baffled reactor. Bioresource Technology, 146, 135-143.

Rabaey K., Rodriguez J., Blackall L., Keller J., Gross P., Batstone D., Verstraete W., Nealson K.H. (2007), Microbial ecology meets electrochemistry: electricity-driven and driving communities. The ISME Journal, 1, 9-18.

Sevda S., Dominguez-Benetton X., Vanbroekhoven K., De Wever H.,Sreekrishnan T.R., Pant D. (2013), High strength wastewater treatment accompanied by power generation using air cathode microbial fuel cell. Applied Energy, 105, 194-206

Sharma Y., Li B. (2010), The variation of power generation with organic substrates in single-chamber microbial fuel cells (SCMFCs). Bioresource Technology, 101, 1844-1850.

Su X.Y., Tian Y., Sun Z.C., Lu Y.B., Li Z.P. (2013), Performance of a combined system of microbial fuel cell and membrane bioreactor: Wastewater treatment, sludge reduction, energy recovery and membrane fouling, Biosensors and Bioelectronics, 49, 92-98.

Sun J., Hu Y., Bi Y.Z., Cao Y.Q. (2009), Simultaneous decolorization of azo dye and bioelectricity generation using a microfiltration membrane air-cathode single-chamber microbial fuel cell. Bioresource Technology, 100, 3185-3192.

Wen Q., Wu Y., Cao D.X., Zhao L.X., Sun Q. (2009), Electricity Generation and modeling of microbial fuel cell from continuous beer brewery wastewater. Bioresource Technology, 100(18), 4171-4175.

Xu F., Mou Z., Geng J., Zhang X., Li C.Z. (2016), Azo dye decolorization by a halotolerant exoelectrogenic decolorizer isolated from marine sediment. Chemosphere, 158, 30-36.

Yang L., Yang H.Y., Shen J.Y., Yang M., Yu H.Q. (2016), Enhancement of azo dye decolourization in a MFC-MEC coupled system. Bioresource Technology, 202, 93-100.

Yasar S., Cirik K., Cinar O. (2012), The effect of cyclic anaerobic-aerobic conditions on biodegradation of azo dyes. Bioprocess and Biosystems Engineering, 35, 449-457.

Yong XY., Feng J., Chen YL., Shi DY., Xu YS., Zhou J., Shu YW., Xu L., Yong C.Y., Sun Y.M., Shi C.L. (2014), Enhancement of bioelectricity generation by cofactor manipulation in microbial fuel cell. Biosensors and Bioelectronics 56, 19-25.

Zhang L., De Schryver P., De Gusseme B., De Myynck W., Boon N., Verstraete W. (2008), Chemical and biological technologies for hydrogen sulfide emission control in sewer systems: a review. Water Res. 42, 1-12.

Zhao F., Rahunen N., Varcoe JR., Roberts AJ., Avignone-Rossa C., Thumser AE., Slade RCT. (2009), Actor affecting the performance of microbial fuel cells for sulfur pollutants removal. Biosensors and Bioelectronics 24, 1931-1936.

Zhao N., Jiang Y., Alvarado-Morales M., Treu L., Angelidaki I., \& Zhang Y. (2018), Electricity generation and microbial communities in microbial fuel cell powered by macroalgal biomass. Bioelectrochemistry, 123, 145-149. 